\title{
KNOWLEDGE ABOUT COVID-19 AS AN ELEMENT OF HEALTH PROFESSIONALS SATISFACTION MANAGEMENT
}

\author{
Aleksandra CZARNECKA \\ Czestochowa University of Technology, Faculty of Management
}

\begin{abstract}
The experience in the fight against the COVID-19 pandemic shows the difficult and sometimes dramatic conditions of medical professionals' work. For most of them, constant exposure to a dangerous virus undoubtedly affects not only their sense of security, but also their satisfaction in terms of functioning in the workplace. In the era of universal and instant communication channels in the form of the Internet and various types of communicators, citizens received various, mostly contradictory and false information about the virus, the situation of the pandemic and the rules of safe functioning within it. It seems, however, that the group of medical professionals, by virtue of their education and occupations, was and is one of the best prepared groups of employees in terms of information. In addition to their knowledge of the virus itself, these employees also have the knowledge of where to find reliable information on the latest scientific reports on the disease. These circumstances undoubtedly shape job satisfaction.

Purpose: The purpose of this article is to present the views of medical professionals regarding their job satisfaction in relation to their access to knowledge and information about the COVID-19 pandemic and their functioning in the workplace.

Design/methodology/approach: The research was conducted in December 2020 on a representative sample of healthcare professionals with the aim to identify their opinions on functioning in the workplace during the COVID-19 pandemic. For the research purposes, the CATI technique was applied with a Likert scale-based questionnaire. The following tests were used for the purpose of data analysis in the STATISTICA program: the KruskalWallis ANOVA on ranks test, the Mann-Whitney test and Pearson's chi-square test. The strength of correlations between the variables was evaluated by means of Spearman's rank correlation coefficient.

Findings: The statistical analysis shown the relationship between the employee access to knowledge and information variables and the job satisfaction variable. Spearman's rank order correlations for the satisfaction index, with $\mathrm{p}<.00100$ in relation to the assessment of how the employer copes with functioning under the COVID-19 pandemic conditions in terms of the flow of information necessary for proper functioning under pandemic conditions (0.4408) and in relation to the assessment of the work organisation in terms of accessibility to knowledge and information on the current situation (0.4344) confirm that better access to knowledge is a factor that increases job satisfaction among medical professionals.
\end{abstract}

Key words: knowledge and information, work satisfaction, healthcare professionals, COVID-19 pandemic

\section{Introduction}

The situation that the world and Poland faced because of the outbreak of the COVID-19 pandemic revealed many weaknesses and problems in the functioning of public systems, economic units, societies and institutions. We are now witnessing a joint international effort to contain and eradicate the virus, the emergence of which has paralyzed the economies of countries but above all exposed all the weaknesses

https://doi.org/10.11118/978-80-7509-820-7-0255

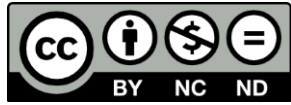


of health systems (Campbell et al, 2013, Rypicz et al, 2020). Medical professionals play a special role during the fight against the pandemic. In Poland, this group includes GUS (CSO- Central Statistical Office, 2018): physicians, dentists, pharmacists, nurses, midwives, physiotherapists, laboratory diagnosticians and paramedics. For years, staff shortages have been observed in Poland (but also in other European countries) resulting, among other things, from many years of negligence in shaping personnel policy in health care (Supreme Audit Office, 2016). The most important of these are: mismanagement of human resources, mismatch between the structure of employment and the profile and scope of services provided, lack of planning in the education system, and underfunding of the health care system (Domagała, 2013). Compared to the world and Europe, the situation of Polish medical personnel is extremely unfavourable. Poland has one of the lowest employment rates in different groups of medical professions in the European Union, unfavourable age structure of doctors and nurses, professional emigration and frequent protests and strikes of different groups of medical professions - resulting from low remuneration and excessive workload (European Union, 2012; Supreme Chamber of Nurses and Midwives, 2021). In such circumstances, Polish healthcare employees were faced with the problem of dealing with the results of the COVID- 19 pandemic. The work of medical professionals also varied at different stages of the pandemic. After a relatively mild wave of infections in spring 2020, a second autumn wave came, which put the Polish health care system on the edge of its operational capacity. The survey, the results of which form the basis of this study, was carried out just after the November peak of infections. Expecting that the results of the study would reveal some interesting patterns related to the functioning of medical professionals in their work environments during the crisis, the authors of the study defined the research problem as follows: How do medical professionals perceive their professional functioning under conditions of the COVID-19 pandemic in the areas of: job security; work organisation; employee relations; and job satisfaction and meaning. The timing of the survey provided an opportunity to explore the views of employees just after the difficult experience of the pandemic which is extremely beneficial in terms of exploring feelings of satisfaction.

The purpose of this article is to present the views of medical professionals regarding their sense of satisfaction in relation to access to knowledge and information about the COVID-19 pandemic and their functioning in the workplace.

\section{Theoretical background to the issue}

Employee attitudes such as satisfaction, commitment, loyalty or responsibility are defined as the views, feelings and reactions in behaviour that a given person displays towards other people, objects or events (Biettel, 2002, p. 62). Robbins (2004, .p 50) defines attitudes as positive or negative evaluations of objects, people or events. Both of these definitions point to the subjectivity of the employee's feelings in the areas in question and the evaluative way in which he or she perceives the organisation as a whole, the phenomena and situations he or she encounters, and the people with whom he or she works. 
Attitudes often overlap and influence each other. Knowledge of employee attitudes and research into them provides information not only on the attitudes themselves, but also on the range of factors that shape them. The importance of the aforementioned employee attitudes, including satisfaction, increases especially in relation to crisis, atypical situations (Stasiuk, 2012) such as functioning under conditions of the COVID-19 pandemic. In these situations, the employee is required not only to comply with generally defined standards of behaviour, but also to fully activate his/her own knowledge, skills and social competences to solve problems arising in the workplace. Identifying and building employee attitudes is also a very important part of human resource management.

Satisfaction is an individual reaction to working conditions - the more they are in line with the employee's expectations, the greater his or her satisfaction with work (The power of commitment ..., http://barometrzaangazowania.com). Caring for the work environment is therefore an expression of the subjective treatment of the employee (Robak, Słocińska, 2012). The adaptation of work and its environment to the employee has an economic dimension in terms of benefits gained or losses not incurred. This directly concerns, among other things, the costs of absenteeism, fluctuation, accidents at work, reduced productivity and quality of work, strikes, or mistakes committed in organisational management. This aspect has recently been particularly highlighted in relation to medical professionals. One group of factors that are related to working conditions are the so-called social working conditions (Robak 2012a; 2012b), i.e. interpersonal relations, relations with superiors (also taking the manner of exercising authority into account (Skolik, 2009, p.71), or communication processes such as sharing knowledge and information (Słocińska 2014, Albrychiewicz-Słocińska 2017). Shortcomings in this area may have a negative effect on the quality of life of the members of the organisation and become a source of stress (Pocztowski, 2007, p.377) and thus affect the sense of job satisfaction and employee commitment.

One of the factors that shape job satisfaction is the need to feel safe. Many authors emphasise that knowledge, skills and competences allow people to co-create not only their own safety, but also the safety of others (Le Morvan, 2016; Breu et al, 2004). By knowledge here we mean both declarative knowledge (I know that), procedural knowledge (I know how to behave) and contextual knowledge (situational applicability of the knowledge possessed giving the answer when? and why?) (Beccari and Heemann 2021; von Krogh et al, 2012; Nonaka, 2007; Botma 2020).

Since organisational systems are also intersubjective networks of meanings (Sułkowski 2016; Słocińska, 2012), the knowledge provided by organisations and distributed within them is provided with a specific context (Bleijenbergh, 2021; Słocińska, 2011) and thus affects the sense of security - it provides a sense of having control over the situation. Everyone, on the basis of the knowledge they have, learns and makes changes in their own knowledge and, consequently, not only in their own behaviour, but also in their attitudes and values (Słocińska, 2013).

With regard to the research findings presented in the study, it was assumed that the medical professional community is equipped with expert knowledge on the development of infectious diseases, the main routes of their spread and the daily safe 
functioning at work. The subject of interest was rather knowledge and information about the pandemic, its scale, dynamics and the changes that are taking place in medical facilities as a result of top-down decisions related to the national pandemic strategy and the role of the employer in this process.

\section{Methodology}

The research results presented in the paper are part of a nationwide quantitative survey of medical professionals carried out as part of the project "Survey of medical professionals' opinions on their functioning under conditions of the COVID-19 pandemic in the workplace" in December 2020, with the participation of the specialist external company DRB Polonia.

The following research assumptions were made in the area of analysing the impact of knowledge on job satisfaction:

- the COVID-19 pandemic situation has affected the sense of job satisfaction of all groups of medical professionals;

- medical professionals have better-than-average access to specialist knowledge concerning the SARS-cov-2 virus and the principles of safe functioning in the workplace during the pandemic.

In the framework of the conducted research the following problem was identified: How do the interviewed medical professionals assess the access to knowledge about COVID 19 and the rules of operation during the pandemic and how does it affect their job satisfaction, in the context of the operation of health care units in crisis resulting from the COVID-19 pandemic situation in Poland?

The study was carried out using quantitative research methods, using the CATI (Computer Assisted Telephone Interview) survey technique. The technique was selected due to the limitations of direct contact resulting from the COVID-19 epidemic in Poland at the time of the study. The research population was made up of medical professionals according to the GUS (Central Statistical Office) classification. The survey comprised a randomly selected representative sample of $\mathrm{N}=384$ medical professionals, determined from the 2018 GUS report (population of medical professionals was: 400,986 individuals).

The research tool used was a standardised questionnaire consisting of closed questions and statements. A Likert scale (the so-called Likert scaling technique) was used for the responses. The research tool - the questionnaire has an authorial character and was formulated by the members of the research team - employees of the Department of Psychology, Sociology and Management Communication of the Faculty of Management, Częstochowa University of Technology.

The STATISTICA software was used in the process of compiling the research results. Non-parametric tests were used to assess the significance of differences in analysed variables: Mann-Whitney U test (UMW), Kruskal-Wallis ANOVA test $(\mathrm{AKW})$. The Spearman's rank correlation coefficient was used to assess the strength of correlations occurring between variables.

In preparing the methodology of the research, due to the unprecedented nature of the phenomenon studied and the prevailing pandemic situation, and the lack of 
literature studies in this area, no research hypotheses were adopted. Whereas, for the purpose of analysing the results of the study, a number of statistical hypotheses were defined regarding the presence of significant differences in the statements of the respondents due to their characteristics and due to the characteristics of the organisations employing them. It was assumed that $\mathrm{H} 0$ is a hypothesis that there are no differences due to the grouping variable, while $\mathrm{H} 1$ is an alternative hypothesis that there are such differences. The study presents only correlations verified by statistical tests allowing to conclude on the regularities occurring in the studied population.

\section{Results}

In relation to the indicator defining the level of satisfaction with the job currently held by respondents, it was noted that only $3.9 \%$ of respondents strongly denied such feelings and $6.3 \%$ declared that they rather do not derive satisfaction from their job at the moment. However, the vast majority of respondents (69.3\%) stressed that they did feel satisfaction with their work. $20.6 \%$ of respondents could not specify whether they felt satisfaction or not. Given the circumstances of the study and the research group, this result is somewhat surprising.

With regard to the evaluation of the level of satisfaction, the following statistically significant differences were observed in the statements of medical professionals due to: family situation, i.e. living with persons whose health the respondents were particularly concerned about (the results of the UMW test ( $p=$ $0.0262)$, at the adopted level of significance $(\alpha=0.05)$ indicate rejection of the verified null hypothesis of the existence of no differences) and the form of employment (AKW p $=0.0453, \alpha=0.05$ ). The analysis of the contingency tables and histograms revealed that those living with people whose health they were particularly concerned about indicated relatively lower levels of satisfaction than other employees. With regard to the forms of employment, on the other hand, those employed under an employment contract declare higher levels of satisfaction than those employed under an employment relationship, contract, contract of mandate or apprenticeship contract).

The study defined the following indicators on employees' access to knowledge and information:

- Whether the employer can cope with functioning under the COVID-19 pandemic conditions with regard to the flow of information necessary for proper functioning under pandemic conditions.

- How do you assess the organisation of work in terms of: accessibility to knowledge and information on the current situation (organisation of meetings, briefings, issuing of orders, etc.)?

In the group of questions related to access to knowledge and information, in the first question assessing the employer in terms of the flow of information necessary for the proper functioning of the workplace, as many as $70 \%$ of respondents considered that employers perform this task very well or well. Only $12 \%$ of respondents in this assessment gave negative or definitely negative opinions. 
Employers' high ratings are reflected in the responses regarding the assessment of work organization in terms of access to information and knowledge through meetings or indirect communication (e-mails, orders, information brochures, etc.) $67 \%$ of good or rather good ratings compared to $11 \%$ of negative ratings. With regard to involving employees in the process of creating procedures for conduct, the results were slightly worse, although the evaluations were mostly positive $(59 \%$ of respondents). The number of those giving negative opinions was slightly higher, but remained at only $13 \%$.

With regard to the overall assessment of the employer in terms of the flow of information necessary to function under pandemic conditions, only one statistically significant difference was observed in the statements of medical professionals employed in the so-called covid hospitals versus those employed in other hospital facilities (UMW $p=0.0173, \alpha=0.05$ ). Employees of the latter rated their employers slightly worse in this respect.

The statistical analysis also attempted to determine the relationship between the employee access to knowledge and information variables and the job satisfaction variable using the Spearman's rank correlation coefficient. Spearman's rank order correlations for the satisfaction index, with $\mathrm{p}<.00100$ in relation to the assessment of how the employer copes with functioning under the COVID-19 pandemic conditions in terms of the flow of information necessary for proper functioning under pandemic conditions (0.4408) and in relation to the assessment of the work organisation in terms of accessibility to knowledge and information on the current situation (0.4344) confirm that better access to knowledge is a factor that increases job satisfaction among medical professionals.

\section{Discussion}

When analysing the research findings, it should be noted that certain limitations have to be taken into account. The first limitation concerns the selection of the sample - although it is representative in terms of the structure of professions within the surveyed population, the survey itself has a questionnaire character and should be repeated in an in-depth and extended form (although it is not possible to repeat the circumstances surrounding the moment of the survey). The second is the fact that the research was carried out after the peak of the autumn infection wave, which was associated with reduced negative tension among respondents and consequently overoptimistic assessments of the issues under study. Another factor that may distort the respondents' statements is the hopeful expectation of a better tomorrow for the vaccination of medical personnel, which began less than a month after the peak of the second wave of infections.

Despite these limitations, the survey results presented here provide an insight into the problem under analysis and indicate a relatively high sense of job satisfaction among medical professionals. Interestingly, no significant differences were observed in the statements of respondents from the different professional groups comprising the population of medical professionals. This is important as some professions, e.g. pharmacists and diagnosticians, were less exposed to the virus than, for example, 
doctors, nurses and paramedics. There are also no significant differences in the statements of respondents employed in public and non-public facilities. Although it is often claimed that in Poland, non-public health system facilities operate much more efficiently than public ones and cope better with staff management problems.

The results confirm that the relatively high satisfaction rates among medical professionals should be linked directly to access to medical expertise and authorities in the workplace.

\section{Conclusion}

The research has led to two important conclusions. The first one is that medical professionals, the occupational group most exposed to infection and burdened with a physically and emotionally demanding job, declare a relatively high sense of job satisfaction, which, however, should be associated mainly with their expertise. The second conclusion is less clear, although a link was observed between access to knowledge about the pandemic and job satisfaction, there is no clear indication of how significant is the role played by the organisation in this process. Definitely this area of analysis should be made more specific and re-examined.

\section{References}

1. Albrychiewicz-Słocińska A. (2017), Sharing Knowledge Environment as an Element of Employees Development, In: Dogan E., Koc S. A. (eds.), Institutions, National Identity, Power, and Governance in the 21st Century, 8th International Conference of Political Economy (ICOPEC 2017), Belgrad, Serbia

2. Beccari, M.N., Heemann, A. (2021), Knowledge, design and technology: a reflection on conceptions of Hume, Kant and Foucault, "Revista Tecnologia E Sociedade", Vol. 17, No 46, pp. 22-36, doi: 10.3895/rts.v17n46.10973

3. Biettel L., 2002, Krótki kurs zarządzania, PWN Wydawnictwo Naukowe, Kraków.

4. Bleijenbergh, I, van Mierlo, J., Bondarouk, T. (2021), Closing the gap between scholarly knowledge and practice: Guidelines for HRM action research, "Human Resource Management Review", Vol. 31, No 2, Article No 100764, doi: 10.1016/j.hrmr.2020.100764

5. Botma, Y. van Rensburg, N.J., Raubenheimer, J. (2020), A competence assessment tool that links thinking operations with knowledge types, "African Journal of Health Professions Education”, Vol. 12, No 4, pp. 175-178, doi: 10.7196/AJHPE.2020.v12i4.1350.

6. Breu, R., Hafner, M., Weber, B., Nowak A. (2004), Systematic design and realization of security-critical inter-organizational workflows, "Information and Communication Technologies and the Knowledge Economy", Vol. 1 pp. 646-653.

7. Campbell, J., Dussault, G., Buchan, J., Pozo-Martin, F., Guerra Arias, M., Leone, C., Siyam, A., Cometto, G. (2013), A universal truth: no health without a workforce. Forum Report, Third Global Forum on Human Resources for Health, Recife, Brazil. Geneva, Global Health Workforce Alliance and World Health Organization.

8. Domagała, A. (2013), Planowanie kadr medycznych systemu zdrowotnego - potrzeba czy konieczność? (Healthcare system medical personnel planning - need or necessity?), "Zeszyty Naukowe Ochrony Zdrowia" (Healthcare Academic Journals), Zdrowie Publiczne i Zarzadzanie (Public Health and Management), Vol. 11, No 2, pp. 148-158.

9. European Union (2012) EU level Collaboration on Forecasting Health Workforce Needs, Workforce Planning and Health Workforce Trends - A Feasibility Study. https://ec.europa.eu/health/workforce/key_documents/study_2012_en (access 15.04.2021). 
10. Główny Urząd Statystyczny, GUS, (CSO - Central Statistical Office) (2018) https://stat.gov.pl/obszary-tematyczne/zdrowie/zdrowie/zdrowie-i-ochrona-zdrowia-w-2018roku, 1,9.html (access 8.03.2021).

11. Le Morvan, P. (2016), Knowledge and Security, "Philosophy", Vol. 91, No 3, pp. 411-430, doi: 10.1017/S0031819116000176.

12. Moc zaangażowania pracowników, Barometr zaangażowania, http://barometrzaangazowania.com (odczyt 15.06.2020).

13. Naczelna Izba Pielęgniarek i Położnych (The Main Chamber of Nurses and Midwives) (2021) "Struktura i średnia wieku pielęgniarek i położnych w Polsce", https://nipip.pl/srednia-wiekupielegniarek-i-poloznych-w-polsce/ (access 15.04.2021)

14. Najwyższa Izba Kontroli (Supreme Audit Office) (2016) Kształcenie i przygotowanie zawodowe kadr medycznych, ( Education and occupational preparation of medical personnel), https://www.nik.gov.pl/kontrole/P/15/060/ (access 15.04.2021)

15. Nonaka, I. (2007), The knowledge-creating company, "Harvard Business Review", Vol. 85, No 7-8, pp. 162-+

16. Pocztowski A. (2007), Zarzadzanie zasobami ludzkimi, Polskie Wydawnictwo Ekonomiczne. Warszawa.

17. Robak E. (2012 a), Równowaga między praca a życiem osobistym pracowników jako istotny czynnik wptywajacy na kapitat ludzki, In: D. Kotlorz (ed.), Ekonomiczne i społeczne aspekty funkcjonowania współczesnego rynku pracy, Studia Ekonomiczne, Zeszyty Naukowe Wydziałowe Uniwersytetu Ekonomicznego w Katowicach, nr 110, Katowice.

18. Robak E. (2012 b), Wsparcie w miejscu pracy a równowaga praca-życie pracowników, „Management”, Vol.16 nr 1.

19. Robak E., Słocińska A. (2012), Role of the Superior in Shaping the Work - Life Balance Amongst Employees, In: Majska konferencija o strategijskom menadzmentu. Studentski simpozijum o strategijskom menadzmentu. Zbornik izvoda radova. Bor, Beograd.

20. Robbins P. S. (2004), Zachowania $w$ organizacji, Wydanie II zmienione, Polskie Wydawnictwo Ekonomiczne, Warszawa.

21. Rypicz, Ł., Witczak I., Rosińczuk J., Karniej P., Kołcz A. (2020) Factors affecting work ability index among Polish nurses working in hospitals - A prospective observational survey, "Journal of Nursing Management", Vol. 00:1-9. doi: 10.1111/jonm.13192.

22. Skolik S.(2009), Władza i kierowanie we współczesnej organizacji. In: F. Bylok, E. Robak (eds) Zachowania ludzi w organizacji. Wybrane zagadnienia.. Wydawnictwo Politechniki Częstochowskiej. Częstochowa.

23. Słocińska A. (2012), Dzielenie się wiedza jako podstawowa kompetencja organizacji struktur sieciowych, „Managment” Vol.16 No, 1, s. 647-659.

24. Słocińska A. (2013), Procesy dzielenia się wiedza jako warunek rozwoju współczesnych organizacji, In: Czech A., Szpilt A. (eds.), Nauki o zarzadzaniu dla przedsiębiorstw i biznesu, Wydawnictwo Uniwersytetu Ekonomicznego w Katowicach, Katowice.

25. Słocińska A. (2014), Społeczne środowisko pracy jako element kształtujący zaangażowanie pracowników, „HUMANIZACJA PRACY, Psychologiczno - społeczne uwarunkowania zaangażowania pracowniczego", Vol 3 (277), s. 111-128.

26. Stasiuk A. (2012), Rola spolecznego środowiska pracy $w$ budowaniu zaangażowania pracowników, „Organizacja i Zarządzanie” Zeszyty Naukowe Politechniki Poznańskiej, Vol 58, ss 75-88.

27. Sułkowski, Ł. (2016). Kultura akademicka. Koniec utopii? (Academic culture. End of utopia?), PWN Warszawa

28. Von Krogh, G., Nonaka, I., Rechsteiner, L. (2012), Leadership in Organizational Knowledge Creation: A Review and Framework, "Journal Of Management Studies", Vol. 49, No 1, pp. 240-277, doi: 10.1111/j.1467-6486.2010.00978.x). 